\title{
16世紀のオスマン朝における土地問題
}

一一東アナトリアに和ける「ティマール制」の施行——

\section{Land Problems of the Ottoman Empire in the 16th Century}

- Timar System in Eastern Anatolia-

\section{三 沢 伸 ${ }^{*}$ 生 $^{*}$}

ABSTRACT There are two main themes about land problems of the Ottoman Empire. From the 19th century to 1940's timar system was most popular subject of study in the frame of Islamic feudalism. But now many scholars are interested in iltizam system and çiftlik.

For all that, there are still unsolved problems about timar system in the scope of the political formation of the Ottoman Empire. This system was not fixed but flexible with regional and periodical variations owing to the political needs.

In the 16th century, the Ottoman Empire grew up an Islamic Empire with its vast territory. In the newly conquered lands, a special land system was putted in force. For example, the mâlikâne. divân̂ $\hat{\imath}$ system, which is a special timar system, was carried out in Eastern Anatolia. By the analysis of two cadastres about Malatya region, BA 387 (1519/20) and TK 142 (1560), the number of villages where the mâlikâne:dîân̂े system in charge (table 1) and the proportion of mâlikâne revenue to the total tax revenue (table 2) suggest that mâlikâne:dîvânर system was step by step changed to the normal timar system during 40 years of the reign of Süleyman I.

I. はじめに

オスマン朝に招いても土地制度は単なる土地制度の枠を越兄て国家・社会体

* 日本学術振興会特別研究員

Researcher of Japan Society for the Promotion of Science 
制を規定するものであった。そのためにオスマン朝社会経済史研究に和いて， 土地問題は最も重要な課題の 1 つされている。

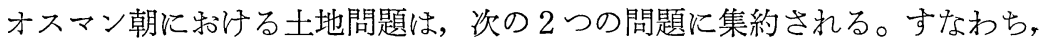
1つは建国から国家体制の根幹をなしていた一種の軍事封土制である「ティマ ール制」であり，もう1つは16世紀末から「ティマール制」の形骸化にともな って取って代わった徵税請負制である「イルティザーム制」と，それにともな い18世紀に急増した私的大土地所有である「チフトリキ」の 2 つである。とり わ忷前者から後者への転換は，オスマン朝の「中世」から「近代」への展開の 指標として認識されて国際的な注目が集まり，現在とても活発に研究が進めら れている問題である。

オスマン朝に括ける近代化の問題は，すなわち中東・バルカン地域に拈ける 近代化の問題であり，世界史上の大問題と認識されて「イルティザーム制」・

「チフトリキ」に研究が集中することは当然である。対照的に，その前段階で ある「ティマール制」は以前は注目を集めたものの，現在ではほとんど顧みら れず，充分な研究が行われていない。しかし，「ティマール制」の解明は単に 「ティマール制」のみならず，「イルティザーム制」・「チフトリキ」の解明に も必要であり，「中世」の指標としてオスマン朝さらにイスラム世界の中に拈 いて「中世」から「近代」への展開を理解するためにも重要である。

研究史的には「ティマール制」はまず「イスラム封建制」研究の一環として その起源を含めて制度史的に扱われた。1930年代からは研究は文書史料を駆使 した社会経済史研究にかわり，その後に個別的な地方史研究の傾向が強まり， 制度の全体像について議論されることないままに放置されるに至った。

こうした従来の研究に共通して見られる特徴は「ティマール制」が固定的な 制度として扱われていることである。しかし，実際の「ティマール制」はオス マン朝の国家形成の進展に応じて，時代的・地域的な特徴を有している。 本稿では，こうした認識に立って，オスマン朝の創成から16世紀に「帝国」 と称されるまでに至る過程で，「ティマール制」が制度としてどのように整備 され，発展し，国家の支配体制の一翼として機能していったのかを見ていく。

\section{II.「ティマール制」の変遷過程}

従来，「ティマール制」の制度史的研究は，起源論もしくは「イルティザー 
ム制」の前提条件としての解体論の 2 つに集中してきた。しかしながら，「テ ィマール制」が制度として整備・形成されていく変遷過程も忘れてはならない。 なぜならば，オスマン朝が国家としての支配体制を確立していく過程に和いて， 「ティマール制」は地方に秃いて，その支配体制を支劣る土台となったからで ある。したがって，「ティマール制」の変遷過程をたどることは，オスマン朝 の支配体制の確立過程をたどることに等しい。

また，従来の研究では画一的に制度の機能面ばかりが注目されていた。それ は，「ティマール制」がオスマン朝の軍事制度・徵税制度・地方行政制度の根 幹をなす政治・社会体制であったからである。しかし，とれ以前の問題として 国家が制度をいかに施行したかという政策面の問題も考慮しなくてはならない。 なぜなら，国家は検地を通じて情報を収集し，地方行政区分を設定・変更した らえで有効に機能する土地制度を施行したのである。オスマン朝は全国で画一 的な土地制度を施行したのではない。「ティマール制」が土地制度の原型であ るにしても，実際には時代的背景や地域差を考慮にいれて柔軟に様々な土地制 度を施行し，地方行政制度を整備し，「帝国」と称されるまでの支配体制を築 きあげたのである。

こらした政策を考慮しながら，「ティマール制」の制度としての変遷を見て いくと，14世紀後半，15世紀後半，16世紀の 3 つの時期に大きな変化が見られ る。そして，16世紀にオスマン朝が「帝国」と称されるまでの国家体制を築き あげた時期に，「ティマール制」は国家の支配体制の土台として制度史的にも 社会経済史的にも最も整備された形態に到達したのである。

初期年代記『アシクパシャザーデ史』には始祖オスマン，第 2 代オルハンの 時代にすでにティマール授与の記述が見られる。しかしながら, 起源論争の紛 紏に見るようにその当時の制度の内容は不明である。たとえティマールの名称 をもつ封土や原初的な「ティマール制」が存在していたとしても，本来の「テ ィマール制」の確立は14世紀後半のムラト 1 世・バヤズィット 1 世の時代に求 められる。なぜならムラト 1 世治世下に常備軍が設置され, 一種の軍事封土で あるティマールに基づく戦士集団への統制・組織化が強まった。また東方のイ スラム世界から文書の知識が導入されながら，国家組織が整備され，検地の害 施と検地帳の作成とが始まり，制度的に「ティマール制」の施行条件が整った。 これを継承したバャズィット1世はアナトリアの諸君侯国を軍事的に征服する 
とともに，大規模に検地を行なって地方行政区画を設定し「ティマール制」を 組織的に施行した。こうしてオスマン朝の君主としてはじめてスルタンの称号 を獲得したバヤズィット1世はオスマン朝を辺境の君侯国からイスラムの伝統 をもつスルタン専制国家へと変えようとしたのだった。

しかしながら，1402年のアンカラの戦いでバヤズィット1世がティムールに 敗北すると，バヤズィット 1 世が征服した新領土は短期間のうちに崩壊する。 すなわち，カラマン侯国をはじめオスマン朝に併合されたはずの旧君侯国領が 復活した。この事実は，旧来の本拠地である西アナトリアを別にして，急澎張 した新征服地では旧勢力がそのままゆるやかにオスマン支配下に組み入れられ たにすぎず，帝国の不可分の一体としてまとめあげるシステムがまだでき上が っていなかったことを示すす。のようにバャズィット1世の治世, 14 世紀後半 は「ティマール制」が制度として整備されたことから，土地制度史上の一時代 をなしたと言える。しかし，制度としての原型は完成したものの，その施行に 際しては問題点が残り，安定した支配体制を築くには至らなかった。

アンカラの戦い以降，メフメト 2 世の治世に至るまでの半世紀は，アンカラ の戦いでの失地回復の時期にあたる。土地制度史的に大きな変化は見られない が，現存する最古の検地帳はこの時期に属し，失地回復と共に検地が実施され 「ティマール制」が施行されていたことが確認される。

15 世紀後半のメフメト 2 世の時代は，オスマン朝が 1 世紀前に喪失した失地 回復を達成し，さらにそれを越えて大規模な領土拡張へと再び乗り出した時期 であり，そのために土地制度史上でも特筆すべき時期である。オスマン朝の支 配組織も 1 世紀前と比較して格段に整備され，スルタンを頂点とする中央集権 体制が築き上げられていた。数多くの法令が編纂され，「ティマール制」につ いても細かく規定された。これらの法令に基づいて検地を実施して「ティマー ル制」を施行する一方, また一部のティマールを没収して直轄地化し，さらに アナトリアに怙ける最大の障害であったカラマン侯国を再征服すると，旧支配 勢力に相当額のティマールを付与してオスマン朝に取り达み,「ティマール制」 による一元的な支配を可能とする国土の統一が図られた。バヤズィット 2 世も 原則的にこうしたメフメト 2 世の政策を継承した。

16世紀を迎えてオスマン朝はルメリ州・アナドル州といらバルカン・西アナ トリアの本拠地を中心として北東アナトリア, 黒海沿岸, アルバニアにまで達 
する大国家に成長していた。その間に，14世紀後半，15世紀後半という2つの 時期を経て，「ティマール制」が整備され，国家の支配体制の基盤をなしてい た。しかし，セリム 1 世・スレイマン 1 世の治世，オスマン朝はイスラム世界 ・バルカン地域の多くを版土に加えて，「イスラム的世界帝国」へと大きく变 質した。それにともない国家の支配体制も著しい発展を遂げ，したがって支配 体制の根本をなしていた「ティマール制」にも新展開が見られた。

セリム 1 世は短い治世の間にマムルーク朝を滅ぼし，イスラム世界の中央に 進出に成功した。これを継承したスレイマン 1 世はイラクを併合し，サファヴ ィー朝を抑光込み, 北アフリカを保護領とし, バルカン地域ではウィーンに迫 るまで領土を広げた。こうした新領地に支配体制を築き上げるために，「ティ マール制」を原則に様々な土地制度を施行して, 検地・地方行政区分の变更を 繰り返しながら，徐々に国家体制の中に組み込む政策が取られていた。

新領土の多くには州が設けられ，一部は属国や部族の自治領に留まり，そう した行政区分の違いに応じて異なる土地制度が施行された。「ティマール制」 が原則であるが，東アナトリアやマムルーク朝領として「イクター制」が施行 されていたシリア地方には「ティマール制」を変形した「マーリキャーネ・デ ィヴァーニー制」が施行された。マムルーク朝の中心であったエジプト地方は 「ティマール制」が施行されず，サルヤーネといら定額の税収を中央に納める ベイレルベイ領となった。北アフリカの多くも, 同様にサルヤーネを納める形 で海軍提督領となり，「ティマール制」は施行されなかった。東アナトリアに 点在する有力なトルコ系・クルド系遊牧民の一部す「コルト制・オジャク制」, と称される部族的自治が認められ，「ティマール制」の枠外に置かれた。

こうした土地問題について，バルカン地方に関してはバルカン諸国に和いて 自国史の一部として，前述のように早くから文書史料を利用した研究が行われ てきたが，一方のイスラム世界に関しては最近まで注とんど関心を集めずに放 置され，研究の蓄積がないのが現状である。

そこで，16世紀にイスラム世界に属する新領土に执いて，「ティマール制」 がどのように施行され，機能していったかの一例として，本拠地である西アナ トリアとイスラム世界の結節点である東アナトリアに注目して分析していく。 


\section{III. 東アナトリアにおける「ティマール制」の施行}

16世紀に新領土の東アナトリアでは，シリア地方と同じく「ティマール制」 を変形した「マーリキャーネ・ディヴァーニー制」が施行されていた。この制 度は「ティマール制」を前提とし，「ティマール制」の枠内で一部に特権を付 与する変形を許容するものである。したがって，この制度が施行された地域で は本来の「ティマール制」が施行される土地と「マーリキャーネ・ディヴァー ニ一制」が施行される土地とが併存する形を呈する。この制度が施行される土 地では，本来の「ティマール制」の原則に反して，1つの土地に対して国家と 旧支配者の 2 つ租税徵収権を設定して, 旧支配者にマーリキャーネ分, 国家 の在地騎兵軍にディヴァーニー分という税収が与えられていた。

この制度の施行により，征服後も勢力を保つ旧支配者を国家の側に取り込み ながら, 同時に在地騎兵軍も設置して, 両者を併用しながら本拠地から遠く離 れた新領土に短期間のうちに支配体制を築くことに成功したのである。

制度の起源はオスマン朝以前, ルーム・セルジューク朝やトルコ系諸君侯国 の時代にすでさかのぼるが，オスマン朝では，15世紀以降の失地回復の時代に アナトリアに和いて失地回復の手段として適用され始めた。しかし法的に整備 され，組織だって施行され始めたのは，まさに16世紀以降の東アナトリア・シ リア地方に括いてである。その意味でこの制度はオスマン朝が「イスラム的世 界帝国」へと変貌するための重要な制度であり，また「ティマール制」自体の 発展を考劣る上で極めて重要である。

\section{IV. マラティヤ地方における事例}

しかしながら，従来の研究ではこの制度については法令を史料とした法制史 的な分析に終始して，この制度が実際にどのように施行され，機能していたの か, さらに本来あるべき「ティマール制」との関係については研究が不充分で あっだ。そこで, 16世紀の東アナトリアのマラティヤ地方に例をとって, 検地 帳を分析してその実態を明らかにする。

分析する史料は，スレイマン 1 世治世の初年掞よび末期に作成された 2 冊の 検地帳である。初年のものは，セリム1世が没し，スレイマン 1 世が即位した 926 (1519/20) 年に作成されたルーム州検地帳であり，末期のものは967 (1560) 年に作成されたマラティヤ県検地帳である。マラティヤ地方は元来トルコ系遊 
牧民のドゥルカドゥル（Dulkadrr）侯国の領土だったが，1515年にセりム 1 世 がドゥルカドゥル侯国に遠征してこれを属国とすると，マラティヤ地方を引き 離してルーム州に併合した。ルーム州はカラマン州と共に本拠地アナドル州以 東の中央・東アナトリアの中核を担ら重要な州である。このときマラティヤ地 方はマラティヤ郡のみで構成されるマラティヤ県, ゲルゲル郡・キャータ郡・ ベヘスニ郡で構成されるゲルゲル県, ディヴリー郡・ダーレンデ郡・フスン・ マンスール郡で構成されるダーレンデ県の 3 県に分けられていた。スレイマン 1 世はこの行政区分を継承したが，1522年にドゥルカドゥル侯国を滅ぼすとル 一ム州から分離して侯国領と合わせて全体でドゥルカドゥル州を新設した。そ の後に何度か検地を行ならが，治世末期の1560年に再び検地を行ない，再びル 一ム州へと区画変更した。その際，マラティヤ地方はマラティヤ郡・ゲルゲル 郡・キャータ郡・ベヘス二郡から構成される県となった。

つまりBA 387はセりム1世が征服した際の検地帳であり，これを継承した スレイマン 1 世何度か検地を行ない，TK 142はその治世最後の検地帳であ る。両者の比較により，セリム 1 世がどのように「マーリキャーネ・ディヴァ 一ニー制」を設定し，それを継承したスレイマン 1 世が治世の間に幾度か検地 を実施して，制度の運営を整備していった実態を明らかにできる。

史料の性格について簡単に触れる。TK 142は典型的な明細悵であり，そこ に記される遊牧民や都市部の情報はすでに分析を試みだこれに対して，B A 387 は特異な明細帳である。法令・都市部の記述には問題ないが，乙かし農村 部の記述が大幅に簡略化されている。すなわち, 納税者の氏名, 封土の保有者 名, 税目とその税額やその他の特記事項が一切省略されて, 納税者人口, 納税 総額, 納税総額に占めるマーリキャーネ分とディヴァーニー分の割り合いだけ が記されるに留まっている。その理由は不明であるが，結果として農村部の情 報が限られ，実態の分析む限定される。そのためか，BA 387を史料として分 析する研究も少なく，マラティヤ地方の研究にも利用されず，その存在が忘れ られていた観がある。しかしながら，情報が限定される欠点を有するものの， セリム 1 世が施行した土地制度の実態を示す数少ない明細帳の一つである。そ こでこれを最大限に分析して，TK 142 と比較を試みる。

「マーリキャーネ・ディヴァーニー制」に着目して, 比較を行なうと, 制度 が施行されていた農村（カリェ, karye）数・耕作地（メズラア, mezra'a） 
数およびその占有率，さらに税収に占めるマーリキャーネ分とディヴァーニー 分の分割比の 2 つが有効な情報を提供する。それを各郡別にまとめたものが，

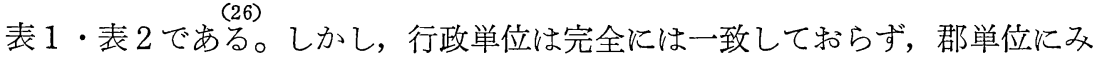
てもディヴリー郡・ダーレンデ郡・フスン・マンスール郡は 1560 年当時は別の 県に属し，同時期に検地は行われておらず，表でも空欄にしてある。

$2 つ の$ 表から，まず40年の間にマラティヤ地方の農業は順調に発展していっ たことがらかがえる。マラティヤ郡・ゲルゲル郡・キャータ郡・ベへス二郡の 4 郡のみの比較になるが，農村・耕作地は $20 \%$ 前後まで増加し，税収も括およ そ 2 倍に伸びていることが分かる。土地制度が順調に機能し，農業生産が発展 していたことをらかがわせる。

\section{V.「マーリキャーネ・ディヴァーニー制」が施行される農村・耕作地}

では土地制度はいかに機能していたのだろらか。従来，土地制度の機能は税 額だけをよりどころに分析されることが多かった。しかし，まず農村・耕作地 において制度がいかに施行されていたかに着目したい。表1に示したように， 何より 1519/20 年当時の「マーリキャーネ・ディヴァーニー制」と本来の「テ ィマール制」の施行状況が目を引く。セりム 1 世がこの地方をルーム州に併合 するにあたって，いかに旧ドゥルカドゥル侯国出身の旧支配勢力の動向を把握 しながら，土地制度を施行していたのかが分かる。第1にマラティヤ郡におい ては，農村で $91.5 \%$ ，耕作地で $74.4 \%$ ，双方の単純合計でも $81.4 \%$ と他の 郡とは異なり，その汪とんどに「マーリキャーネ・ディヴァーニー制」が施行 されていた。これはマラティヤ郡がマラティヤ地方の中心として旧支配勢力の 拠点であったことに如実に示している。マラティヤ郡に次いで高い数字を示す のは農村・耕作地ともに $50 \%$ 以上の数字を示すディヴリ一郡で，あとはゲルゲ ル郡・キャータ郡・ベヘス =郡の3 郡が農村で $20 \sim 40 \%$ ，耕作地で $15 \%$ 前後の 占有率で横並びであり，ダーレンデ郡とフスン・マンスール郡が農村では若干 差はあるものの，23.6\%と10.5\%と低く，耕作地ではさらに $5 \%$ と極端に少な い占有率である。ディヴリー郡・ダーレンデ郡・フスン・マンスール郡に旧支 配勢力がどれだけ展開していたかは不明であるが，キャータ郡・ベヘス二郡・ ゲルゲル郡では彼らの勢力がマラティヤ郡ほど強くなく，さらにゲルゲル郡で は異質の遊牧民が展開していたことが分かっている。このよらに「マーリキャ 
表 1 「マーリキャーネ・ディヴァーニー制」が施行される農村・耕作地数

\begin{tabular}{|c|c|c|c|c|c|c|}
\hline & \multicolumn{3}{|c|}{$1519 / 20$ 年（B A 387） } & \multicolumn{3}{|c|}{ 1560年（TK 142） } \\
\hline & 農 村 & & 合 計 & 農 村 & 耕 & 合 計 \\
\hline 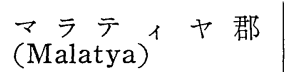 & $\begin{array}{l}226 / 247 \\
(91.5 \%)\end{array}$ & $\begin{array}{l}264 / 355 \\
(74.4 \%)\end{array}$ & $\begin{array}{l}490 / 602 \\
(81.4 \%)\end{array}$ & $\begin{array}{l}145 / 292 \\
(49.7 \%)\end{array}$ & $\begin{array}{c}63 / 432 \\
(14.6 \%)\end{array}$ & $\begin{array}{l}208 / 724 \\
(28.7 \%)\end{array}$ \\
\hline $\begin{array}{l}\text { ゲ ル ゲ ル 郡 } \\
(\text { Gerger) }\end{array}$ & $\begin{array}{r}46 / 126 \\
(36.5 \%)\end{array}$ & $\begin{array}{l}24 / 172 \\
(14.0 \%)\end{array}$ & $\begin{array}{r}70 / 298 \\
(23.5 \%)\end{array}$ & $\begin{array}{l}8 / 153 \\
(5.2 \%)\end{array}$ & $\begin{array}{l}6 / 183 \\
(3.3 \%)\end{array}$ & $\begin{array}{c}14 / 336 \\
(4.2 \%)\end{array}$ \\
\hline$\underset{(\text { Kahta) }}{\neq}+$ タ 郡 & $\begin{array}{l}37 / 93 \\
(39.8 \%)\end{array}$ & $\begin{array}{l}63 / 386 \\
(16.3 \%)\end{array}$ & $\begin{array}{l}100 / 479 \\
(20.9 \%)\end{array}$ & $\begin{array}{l}22 / 135 \\
(16.3 \%)\end{array}$ & $\left(\begin{array}{r}10 / 410 \\
2.4 \%)\end{array}\right.$ & $\begin{array}{r}32 / 545 \\
(5.9 \%)\end{array}$ \\
\hline$\underset{\text { (Behesni) }}{\text { 지 }}=$ 郡 & $\begin{array}{r}14 / \\
(20.9 \%)\end{array}$ & $\begin{array}{l}55 / 353 \\
(15.6 \%)\end{array}$ & $\begin{array}{l}69 / 420 \\
(16.4 \%)\end{array}$ & $(12 / 6 \%)$ & $\begin{array}{c}29 / 354 \\
(8.2 \%)\end{array}$ & $\begin{array}{c}41 / 442 \\
(9.3 \%)\end{array}$ \\
\hline $\begin{array}{l}\text { ディ ヴ リ } \\
\text { (Divriğ) }\end{array}$ & $\begin{array}{r}79 / 114 \\
(69.3 \%)\end{array}$ & $\begin{array}{r}88 / 172 \\
(51.2 \%)\end{array}$ & $\begin{array}{l}167 / 286 \\
(58.4 \%)\end{array}$ & & & \\
\hline $\begin{array}{l}\text { ダーレンン デ 郡 } \\
\text { (Darende) }\end{array}$ & $(23.6 \%)$ & $\begin{array}{l}7 / 133 \\
(5.3 \%)\end{array}$ & $\begin{array}{l}20 / 188 \\
(10.6 \%)\end{array}$ & & & \\
\hline $\begin{array}{l}\text { フスン・マンスール郡 } \\
\text { (Husn Mansur) }\end{array}$ & $\begin{array}{r}9 / \\
(10.5 \%\end{array}$ & $\left(\begin{array}{l}2 / 37 \\
5.4 \%)\end{array}\right.$ & $\left(\begin{array}{rl}11 \\
8\end{array}\right.$ & & & \\
\hline 計 & $\begin{array}{l}424 / 788 \\
(53.8 \%)\end{array}$ & $\begin{array}{l}503 \\
(32 \\
\end{array}$ & $\begin{array}{l}92 \\
(38 \\
\end{array}$ & $\begin{array}{l}187 / 6 \\
(28.0 \%\end{array}$ & $\begin{array}{r}108 \\
(7 .\end{array}$ & $(14$ \\
\hline
\end{tabular}

項目内の, 右側の数字が農村・耕作地の総数であり, 左側の数字が「マーリキャーネ

・ディヴァーニー制」が施行される農村・耕作地数である。したがって，右側の数字 から左側を引くと本来の「ティマール制」が施行される農村・耕作地数になる。括弧 内は百分率。

ーネ・ディヴァーニー制」は決して一律的に施行されたのではなく，恐らくは 検地の際の詳細な調査に基づき，政治的判断によって土地制度が施行されてい たことが分かる。強力な旧支配勢力に対しては妥協して「マーリキャーネ・デ ィヴァーニー制」を施行し，逆に問題がないと判断された場合には通常の「テ ィマール制」を施行してその勢力を抑え达んでいったのである。

では，スレイマン 1 世の治世を通してその施行状況はどら変化したのだろら か。表 1 で両方に含をれる4つの郡についてBA 387 と T 142を比較すると 歴然たる変化が生じている。農村数・耕作地数の自然増加を割り引いて考㝋て も,「マーリキャーネ・ディヴァーニー制」の施行が激減していることが分か る。マラティヤ郡では農村での占有率が $91.5 \%$ か $49.7 \%$, 耕作地での占有率 はさらに激しく74.4\%から14.6\%にまで落ち込んでいる。他の 3 郡での占有率 も同じである。ゲルゲル郡は農村で $5.2 \%$ ，耕作地で $3.3 \%$ ，キャータ郡は農村

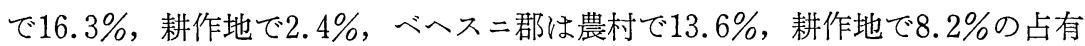
率を占めているに過ぎない。最も落ち込みが激しいゲルゲル郡は上記のよらに 
表 2 「マーリキャーネ・ディヴァーニー制」による税収分割（単位：アクチェ akçe）

\begin{tabular}{|c|c|c|c|c|c|c|}
\hline & \multicolumn{3}{|c|}{ 1519/20年（B A 387） } & \multicolumn{3}{|c|}{ 1560年（T K 142） } \\
\hline & M 分 & D 分 & 合 計 & $\mathrm{M}$ 分 & 分 & 合 計 \\
\hline$\underset{\text { (Malatya) }}{\text { マ }}$ & $\begin{array}{r}321608 \\
(26.4 \%)\end{array}$ & 896057 & 1217665 & $\begin{array}{l}395176 \\
(21.6 \%)\end{array}$ & 1440903 & 1836789 \\
\hline $\begin{array}{l}\text { ゲ ル ゲ } \\
\text { (Gerger) }\end{array}$ & $\begin{array}{r}46506 \\
(11.6 \%)\end{array}$ & 355389 & 401895 & $\begin{array}{r}19791.5 \\
(2.5 \%)\end{array}$ & 769275 & 789066.5 \\
\hline $\begin{array}{l}\text { キ } \\
(\text { Kahta })\end{array}$ & $\begin{array}{r}36890 \\
(7.7 \%)\end{array}$ & 442927 & 479817 & $\left(\begin{array}{c}49328 \\
5.0 \%\end{array}\right)$ & 939631 & 988959 \\
\hline 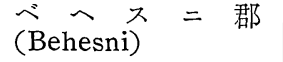 & $\begin{array}{r}24893 \\
(6.9 \%)\end{array}$ & 336444 & 361337 & $\begin{array}{c}53940 \\
(7.9 \%)\end{array}$ & 629953 & 683893 \\
\hline 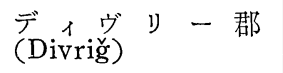 & $\begin{array}{r}93892 \\
(19.2 \%)\end{array}$ & 394321 & 488213 & & & \\
\hline $\begin{array}{l}\text { ダーレンン デ 郡 } \\
\text { (Darende) }\end{array}$ & $(7.8 \%)$ & 243163 & 263856 & & & \\
\hline $\begin{array}{l}\text { フスン・マンスール郡 } \\
\text { (Husn Mansur) }\end{array}$ & $\begin{array}{r}19639 \\
(9.7 \%)\end{array}$ & 181801 & 201440 & & & \\
\hline 計 & $\begin{array}{r}564121 \\
(16.5 \%)\end{array}$ & 2856102 & 3414223 & $\begin{array}{l}518235.5 \\
(12.1 \%)\end{array}$ & 79762 & 4299417.5 \\
\hline
\end{tabular}

$\mathrm{M}$ 分：マーリキャーネ分, D分：ディヴァーニー分

また括弧内は郡の全税収に占めるマーリキャーネ分の税収の百分率。

旧支配勢力に関係ない遊牧民が排除されたことが原因であろらか。これらの数 字は旧支配勢力の拠点であるマラティヤ郡に拈いては，激減したとはい方依然 として旧支配勢力を考慮して「マーリキャーネ・ディヴァーニー制」が残存す るが，他の 3 郡に和ける施行状況はもはや「マーリキャーネ・ディヴァーニー 制」は本来の「ティマール制」に置換されつつあることを示している。スレイ マン 1 世の時代に幾度か実施された検地と行政区画変更の主眼は，恐らく「マ ーリキャーネ・ディヴァーニー制」を「ティマール制」へと漸次変更して本拠 地であるアナドル州・ルメリ州に打る土地制度に近つけ，国家の統一を図る ための政策の一端であったのである。

\section{VI.「マーリキャーネ・ディヴァーニー制」による税収分割}

次に，こうした政策を税収に和ける「マーリキャーネ分」の占有率から分析 するとどらいら結果が得られるだろらか。表 2 で 1519/20年に沶ける税収分割 を見ると, やはりマラティヤ郡が $26.4 \%$ 一番高い数字を示し, 「マーリキャ 一ネ・ディヴァーニー郡」が強く施行されていたことを物語っている。マラテ ィヤ郡に次いでディヴリー郡が $19.2 \%$ 占有率を示すことも上と同じであり， 
恐らくはこの郡に和ける旧支配者の勢力が強かったことをらかがわせる。その 他の郡では $6.9 \%$ から $11.6 \%$ まで開きはあるが，施行される農村数・耕作地数 の占有率の差涪どその開きは大きくない。すなわちダーレンデ郡とフスン・マ ンスール郡では施行される農村数・耕作地数が少ないもののそのマーリキャー ネ分は高いのである。これは両郡では旧支配者のなかでも税収が多い有力者以 外は排除され，「マーリキャーネ・ディヴァーニー制」ではなく本来の「ティ マール制」が施行されたことを示すのであろら。同じマラティヤ地方にありな がら，行政区画では両郡がダーレンデ郡とともに別の県に編入されていること も有力な旧支配者間の連係を防ぎ，隔離する政策意図があったのであろら。

また，表 2 で両方に含まれる 4 つの郡についてBA 387 と T 142を比較す ると，マラティヤ郡が $21.6 \%$ ，ゲルゲル郡が $2.5 \%$ ，キャータ郡が $5.0 \%$ ，べへ スニ郡が $7.9 \%$ と，ゲルゲル郡を除いて，農村数・耕作地数に見られたような 際立った減少がなく，ベヘスニ郡に至っては逆に微増している。だが，ベへス 二郡の増加はマーリキャーネ分自体の増大の結果というよりは, 農業生産の自 然増加の結果にすぎないのであろら。ゲルゲル郡の減少は先に述べた遊牧民の 排除が減少の原因であろら。B A 387に封土の保有者名が記されていないため に，確定はできないが，マラティヤ郡・キャータ郡・ベへス二郡の状況は，先 のダーレンデ郡とフスン・マンスール郡の場合と同じく, 税収の多い有力な旧 支配者を温存し, 旧支配者のうち比較的劣る税収の少ない者の農村・耕作地で 「マーリキャーネ・ディヴァーニー制」を廃止したために, 税収面では減少が 農村数・耕作地数での施行状況の減少に比べて少ないものと思われる。

\section{VII. おわりに}

以上のように，オスマン朝は新征服地に対しても検地を実施して詳細なる情 報を集め, 支配体制の確立のために本拠地で施行する「ティマール制」ではな く,「マーリキャーネ・ディヴァーニー制」のように変形した土地制度を施行 したのであった。しかし，それは恒久的な複数の土地制度の併存を意図したも のではなく，常に状況を把握しながら，頻繁に検地と行政区分の変更を行なっ て漸次，本来の「ティマール制」に近づけようとしていたのであった。その意 味に扔いて，やはりオスマン朝を支觉る土地制度は「ティマール制」であり， この制度でもって一元的な国家体制を築こうとしていたのである。 
16世紀のオスマン朝による軍事遠征の華々しい成果はよく知られているが， こうして獲得された新領土をいかにして束社て「イスラム的世界帝国」を運営 していったかについては研究が少ない。この問題を土地制度から見ると，前述 のように15世紀後半にメフメト 2 世・バヤズィット 2 世の治世に大国家として の基盤を得たオスマン朝は，16世紀に獲得した新領土については検地を通して 詳細な調査を行ない，地域差を考慮して地域の実情に応じた土地制度を施行し て，緩やかに統一された「帝国」を築いたのである。東アナトリア（さらにシ リア）の場合，それが本来の「ティマール制」を変形した「マーリキャーネ・ ディヴァーニー制」であった。しかしこの制度は永久的に旧支配者の特権を保 証する制度ではなく，正常な「ティマール制」へ漸次変更し，東アナトリアに 本拠地と均質的な土地制度を実現して統一を図る，言い換えれば東アナトリア を「オスマン化」するための暫定的な土地制度であった。

では，こう「ティマール制」の施行に基づく東アナトリアの「オスマン化」 は成功したのだろらか。マラティヤ地方の事例はオスマン朝の絶頂期と目され るスレイマン 1 世の時代に「オスマン化」が進んだように思わせる結果を示し てはいる。しかし，同時に16世紀後半から17世紀にかけて，この東アナトリア とシリアに拈いて，「ジェラーリー諸反乱」と称される一大地方反乱が勃発し て，さらに「ティマール制」自体が破綻を来たしたことを忘れてはならない。

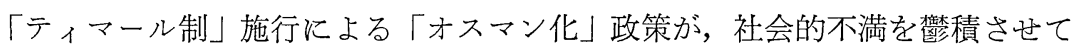
「ジェラーリー諸反乱」に至った側面も否定できない。

以上のことから，オスマン朝を支觉た「ティマール制」は施行の時期，施行 された地域の特殊性を考慮しなければ，その実態が解明できないことがはっき りした。さらにその時代差・地域差にはオスマン朝の支配体制確立のための政 策が反映されていることが分かった。こうした観点にたち，「ティマール制」 以外にもさらに「ユルト制・オジャク制」や「サルャーネ型」なども含めた， オスマン朝全土の土地問題を分析することによって，はじめて「イスラム的世 界帝国」としてのオスマン朝がその版土に確立した支配体制の実態の解明が可 能となろら。

注

（1）「ティマール制」「「イルティザーム制」・「チフトリキ」など土地問題の基本的事 
項については, 永田雄三「西アジア封建社会論」『中世史講座・5：封建社会論』東 京 : 学生社, 1985年, 138-164頁, 同「トルコに拈ける前資本主義社会と「近代化」」 大塚久雄（編）『後資本主義の展開過程』東京 : アジア経済研究所, 1973年, 139-187 頁。

(2) 最近の研究成果は, Çağlar Keyder \& Faruk Tabak (eds.), Landholding and commercial agriculture in the Middle East, New York, 1991. 参照。

（3）研究史については，永田雄三「オスマン朝のバルカン支配をめぐる諸問題——テ ィマール制汇関する研究動向を中心として—」『「トルコ民族とイスラム」に関する 共同研究報告』東京: 東京外国語大学アジア・アフリカ言語文化研究所, 1975年, 6687頁。しかしながら，個々の研究の評価をめぐっては著者には異論がある。

（4）起源論争については稿を改めて論ずる予定である。

（5）今までにるこうした研究がないわけではなかった。直接に「ティマール制」を論 ずるのではないが，「ティマール制」を通してのオスマン朝の支配体制を解明したも のとして, Halil İnalc1k, "Ottoman methods of conquest", Studia Islamica, 2, 1954, pp. 103-129, 米林仁「オスマン朝初期のベイレルベイリク制」『アジア・アフ リカ言語文化研究』24,1982年, 133-180頁。

（6）現在に至るまで「ティマール制」研究の唯一の単行本であるベルディジェアヌの 専論は，機能面を重視する制度的な研究の集大成と言光る。好著であるが，法制史の 観点からの分析に終始して，残念ながら検地帳の分析結果に基づいた実際の施行状況 までは明らかにされていない。Nicoară Beldiceanu, Le timar dans l'état ottoman, Wiesbaden, 1980.

(7) 'Așikpaşazâde (F. Giese, ed.), Die altosmanische chronik des 'Ašikpašazâde, Leipzig, 1929 (rep. Osnabrück, 1972), p. 22, 42, id. (Ali Bey ed.), 'Aşikpaşazâde Tarihi, İstanbul, 1322 (1913/14), pp. 20-21, 45.

(8) İnalcık, op. cit., p. 110.

（9） İnalc1k, op. cit., pp. 104-105. バヤズィット1世時代に作成されたであろら検 地帳は現存しないが，現存する検地帳の記述から確認される最古の検地の記録はその 治世下に行われたことを示す。H. İnalc1k (ed.), Hicri 835 Tarihli Sûret-i Defter-i Sancak-i Arvanid, Ankara, 1954, pp. iii-r.

(10) Inalc1k, "Ottoman methods of conquest", p. 105.

（11）鈴木董『オスマン帝国』東京：講談社，1992年，55頁。

（12） $1431 / 32$ 年付アルバニア県検地帳。註 ( 9 参照。

（13）代表的なものは, Kavânîn-i Al-i 'Osmanî (Topkap1 Sarayı Müzesi Kütüphanesi, Revan Köşü̈ No. 1935). 他の法令については, Ahmed Akgündüz, Osmanlı Kanunnâmeleri ve Hukukî Tahlilleri, vol. I- , İstanbul, 1990- , vol. I., pp. 303-631.

(14) İnalc1k, op. cit., p. 118. 
（15）現存する検地帳はメフメト 2 世・パヤズィット 2 世からその数を増す。Başbakanlık Osmanlı Arşivi Rehberi, Ankara, 1992, pp. 186-228.

（16）幾つか間違いが見られるが，とりあえず, Donald Edgar Pitcher, An Historical Geography of the Ottoman Empire, Leiden, 1972, pp. 100-123, map XXI., H. Inalcık, The Ottoman Empire: the classical age 1300-1600, London, 1973, pp. 104-110.

（17）この制度の内容は，拙稿「オスマン朝の検地帳に見える遊牧民」『アジア・アフ リカ言語文化研究』38，1989年，9-12頁。

（18）制度の起源については確定されていないが，ルトフィ・バルカンは諸君侯国時代 にまで, ベルディジェアヌはルーム・セルジューク朝にまでさかのぼると主張してい るほか, ヴェンズケはシリアに和いてはマムルーク朝に起源がある可能性を示唆して いる。Ömer Lütfi Barkan, “Türk-İslam Toprak Hukuku Tatbikatının Osmanlı İmparatorluğunda Aldığ 1 Şekilleri I: Mâlikâne-Divânî Sistemi”, Türk Hukuk ve Íktisat Tarihi Mecmuası, 2, 1939, pp. 133-134, Irène Beldiceanu-Steinherr, "Fiscalité et formes de possession de la terre arable dans l'Anatolia préottomane”, Journal of the Economic and Social History of the Orient, 19, 1976, pp. 241-248, Margaret L. Venzke, “Aleppo's Mâlikâne-Dîvânî System”, Journal of American Oriental Society, 106-3, 1986, pp. 461-469.

（19）上記の研究に沶いて検地帳は史料とされてはいるものの，ルトフィ・バルカンも ベルディジェアヌも検地帳に付せられた法令の分析が主体で，税収などの数值は核と んど报われず，ヴェンズケは税収の計算を行いながらも税の分析を重視し，数值を活 用し切れていない。このほか，イスラムオウル・イナンが検地帳に含まれる情報を整 理して「マーリキャーネ・ディヴァーニー制」について言及するが，農業生産が中心 のために, 土地問題の観点からは分析は不充分である。Huri İslamoğlu-İnan, “State and peasants in the Ottoman Empire", in The Ottoman Empire and the World Economy (Huri İslamoğlu-İnan ed.), Cambridge, 1987, pp. 107-126.

（20）当時のマラティヤ地方については，拙稿，前揭，5-6頁。

（21）前者はイスタンブルの総理府古文書総局に 387 番の整理番号で，後者はアンカラ の地券および地籍簿総局に 142 番の整理番号で所蔵される。以後, 前者をB A 387 , 後者をTK 142 と略称する。

（22）地方の行政区分である州・県・郡・郷は，しばしば区画変更された。この頃のマ ラティヤ地方については, Tayyib Gökbilgin, “15 ve 16. Asırlarda Eyâlet-i Rûm”, Vakıflar Dergisi, 6, 1965, pp. 51-61, Akgündüz, op. cit., vol. 3, pp. 355-358, vol. 6, pp. 191-192.

（23）スレイマン 1 世治世に実施された検地ごとの変化については，3 冊の明細帳の比 較による分析を別稿で論ずる予定である。

（24）拙稿, 前掲書, 同「オスマン朝治下のアナトリアの都市」『イスラム世界』37・ 
38，1992年， 61-84頁。

（25）ＢＡ 387を利用した研究としては，ルトフィ・バルカンが先駆的であるが，県別 に税の総額を分析したに留まっている (Ö. L. Barkan, op. cit., pp. 134-138.)。 ドゥルカドゥル侯国研究の権威であるイナンチは一切利用しておららず (Refet Yinanç \& Mesut Elibüyük eds., Kanunî Devri Malatya Tahrir Defteri (1560), Ankara, 1983, p. ix, R. Yinanç, Dulkadir Beyliǧi, Ankara, 1989, pp. 156-157.), 総理府 古文書総局目録の地域別索引でマラティヤの項目に記されていない（Başbakanlık Osmanli..., p. 209.)。

（26）実際には, 郡を構成する郷別, さらに郷を構成する各農村・耕作地別に数值を示 すことが可能であるが，本稿では土地問題の観点からの全体像の比較を行ならために 郡単位で結果を表にまとめた。ルトフィ・バルカンは「マーリキャーネ・ディヴァー ニー制」が施行される地域で県単位に税収を分析して制度の施行状況を図る指標を立 てたが，制度の施行は県単位ではなく郡単位で分析しなければ，その実態を正確に分 析することはできない。ルトフィ・バルカンの呈示する指標も有効ではない(Barkan, op. cit., pp. 134-146.)。

（27）ＢＡ 387には省略されるが，TK 142には含まれる諸情報の分析からもマラティ ヤ郡が旧支配勢力の牙城であったことが分かる（拙稿「オスマン朝の検地帳に見える 遊牧民」，23頁)。

（28）同上，23-24面。

（付記）小稿作成にあたり，B A 387の史料的重要性を教授されたマルマラ大学アタチ ュルク教育学部講師エルハン・アフヨンル（Erhan AFYONLU）氏に感謝致 します。 